\title{
Article
}

\section{Analysis of United Kingdom Off-Highway Construction Machinery Market and Its Consumers Using New-Sales Data}

Holt, Gary David and Edwards, David J.

Available at https://clok.uclan.ac.uk/6469/

Holt, Gary David and Edwards, David J. (2013) Analysis of United Kingdom OffHighway Construction Machinery Market and Its Consumers Using New-Sales Data. Journal of Construction Engineering and Management, 139 (5). pp. 529537. ISSN 0733-9364

It is advisable to refer to the publisher's version if you intend to cite from the work. http://dx.doi.org/10.1061/(ASCE)C0.1943-7862.0000584

For more information about UCLan's research in this area go to http://www.uclan.ac.uk/researchgroups/ and search for <name of research Group>.

For information about Research generally at UCLan please go to http://www.uclan.ac.uk/research/

All outputs in CLoK are protected by Intellectual Property Rights law, including Copyright law. Copyright, IPR and Moral Rights for the works on this site are retained by the individual authors and/or other copyright owners. Terms and conditions for use of this material are defined in the policies page.

\section{CLoK}

Central Lancashire online Knowledge www.clok.uclan.ac.uk

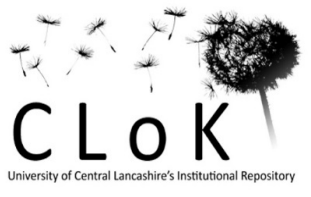




\title{
Analysis of UK Off-highway Construction Machinery Market and its Consumers, using New-Sales Data
}

\author{
Gary D. Holt Ph.D. ${ }^{1}$ and David J. Edwards Ph.D. ${ }^{2}$
}

\begin{abstract}
The off-highway construction machinery market and its consumers have attracted minimal previous research. This study addresses that void by analysing annual UK (volume/portfolio) new-sales data for the ten most popular products within that market, 1990-2010 inclusive. Graphical, descriptive statistical, Pearson-correlational, auto-correlational and elementary modelling are employed to identify: contrasts in sales regarding high- and low-volume items; growth trends and significant recessionary effects on volumes; a demand 'change-point' circa 1997 since when annual product portfolio has changed little; and 'product associations' in consumer demand. Significant association is demonstrated between demand and construction output, especially, with the value of new housing. Subsequently, consumption of wheeled loaders is modelled using construction volume and demand for mini- and crawler-excavators is modelled using new housing data. Time series trends for these machinery types are presented and forecast until 2015. The primary contribution of this study is a deeper understanding of the UK new machinery market and the predilections of its consumers over the last two decades (to present).
\end{abstract}

Author keywords: Machinery; market sector; supply; sales; demand

\footnotetext{
${ }^{1}$ Professor of Innovation in Machinery Management, Centre for Business, Innovation and Enterprise, Birmingham City University, B42 2SU, England. Email: Gary.Holt@bcu.ac.uk T: +44 (0)121 3315381.

${ }^{2}$ Professor of Industrial Innovation and Director, Centre for Business, Innovation and Enterprise, Birmingham City University, B42 2SU, England. Email: David.Edwards@bcu.ac.uk T: +44 (0)121 3316252.
}

Acknowledgement: The authors are most grateful for the thought-provoking and constructive comments of the anonymous reviewers that helped focus and improve the paper considerably. 


\section{Introduction}

This study analyses the UK off-highway construction machinery market and its consumers; as characterised by annual new-sales (product and portfolio) data for the period 1990-2010 inclusive. The term 'off-highway' refers to machinery that is able to operate on topography unsuitable for public highway vehicles and when combined with the term 'machinery' in this way, typically refers to selfpropelled vehicles designed to do work, such as an excavator or a dump truck (Edwards and Holt, 2009a). Any reference hereafter to machinery retains this specific connotation and does not include for instance, other forms such as stationary (e.g. concrete batching) machinery, or small (e.g. hand-held) machines. Machinery types at the focus of this study are the ten highest volume new-sales variants used within UK construction viz: articulated dump truck; rigid dump truck; crawler excavator; wheeled backhoe; mini-excavator; wheeled loader; wheeled excavator; skid-steer loader; compact tracked loader; and telehandler (Sharp, 2011). Table 1 provides a brief description of these types along with their respective acronyms frequently used hereafter for brevity.

[Table 1]

\section{The interaction of machinery supply, demand and supply chain}

Machinery sales occur within an environment conveniently characterised from two standpoints. On the supply side, original equipment manufacturers (OEMs) market their products on the basis of technical innovation and user benefits such as improved safety, economy and environmental friendliness. For example, a UK OEM recently launched a 'cleaner' excavator engine complying with new legislative limits on diesel particulate emissions (EPA, 2011), that removes the need for exhaust particulate filtration and offers up to ten per cent decrease in fuel consumption. From the demand side, buyers constantly seek maximum productivity at minimal costs, while their machinery must also cope with changes in working practices and evolving environmental or health and safety requirements. 
Other factors impacting the supply and demand interface include buyer confidence that is influenced by economic 'climate', availability of funds and projected workload. Machinery economic life plays an obvious role and is a trade-off between optimal replacement cycle and capital cost to achieve this. Geographical characteristics can impart a socioeconomic impact on sales portfolio. For instance, the backhoe loader has proved popular among commonwealth countries but less so in China, although economic power shift from the G8 and emergence of the BRIC ${ }^{[1]}$ is changing the global sales landscape. OEM strategy and resulting competition/price levels affect consumption and the situation has become more complex of late given OEM mergers and acquisitions. The availability of used machinery can influence new sales as can product migration resulting from any combination of the above. The resultant of these influences are ultimately reflected in sales numbers and portfolio; the focus of this study.

Resulting machinery supply chain interactions are mainly dyadic business-to-business (B2B relationships, principally, between OEMs and private sector hire and lease consumers. Additional demand emanates from construction contractors who purchase for in-house fleets; other sectors of industry such as agriculture and quarrying; and sole traders or small-medium-size enterprises who supply machinery on an 'owner-operator' or subcontract work-package basis respectively. Figure 1 displays these interactions and their relationship to external OEM supply and demand influence along with flow of OEM product innovation and concomitant marketing; and influence of consumer demands on product development.

[Figure 1]

Figure 1 is based on the intersect of suppliers and customers (Segerstedt and Olofsson, 2010); whereby such interface represents the (supply/demand) 'system integrator' and the demand chain is symbolized using tiers. Hence, primary tier (T1) represents machinery sales to the private hire and lease sector; while other first-level purchasers are subcontractors $\left(\mathrm{Tl}_{2}\right)$; and main contractors or other sectors of 
industry such as agriculture $\left(\mathrm{Tl}_{3}\right)$. Alternatively, subcontractors may utilise the hire sector, making them a second tier consumer (T2); as might main contractors $\left(T 2_{2}\right)$. If end-users employ machinery from subcontractors or work-package suppliers they become a third tier consumer (T3).

\section{Brief overview of machinery consumption}

Machinery has been increasingly utilised in developed economies to increase production, reduce labor costs and sustain production (Haycraft, 2011). Accordingly, over the last century new machinery sales have grown but recent global economic downturn has seen consumer demand fall per-se and in the UK especially, this has led to significant contraction of machinery sales. The two decades preceding 2008 saw UK machinery sales thriving and somewhat belie the post-2008 downturn. Up until the mid1990s the backhoe loader, personified as the 'JCB', was the item of choice among that sales portfolio (Ashcroft, 2007) while other machinery items in high demand included telehandlers, mini-excavators and crawler excavators (Edwards and Holt, 2010a). Such demand was mirrored elsewhere, for instance, in Australia, India and Brazil but China led the way achieving growth to $6.5 \%$ of total world machinery sales in 2007, up from 2.5\% the previous year (Sleight, 2007).

\section{Why analyse machinery sales?}

The benefits of market analysis include that it can provide key information on: market share (Lancaster and Massingham, 2010); portfolio and products falling into decline (Blythe, 2010); production decisions (Smyth, 2000); and forecasting (Piercy, 1993). Forecasting is particularly important for resource planning and especially in the machinery sector; given that B2B demand has become uncertain over recent years (Kalchschmidt, et. al., 2006). Planning in turn supports business decisions and encourages organisational learning (Ivert and Jonsson, 2010). Nakano (2009) highlighted that sales analysis helps optimise production, while Wanke and Zinn (2004) identified that it assists in deciding whether to make to order or stock and employ push or pull inventories. 
In addition to 'numbers', sales analysis can indicate customers' longer-term intentions thereby anticipating future product needs (Cuganesan, 2008). This can aid innovative product delivery that aligns with demand chain management (DCM), whose goal is competitive advantage by differentiating product delivery process(es) (Hilletofth et. al., 2009, p1181). Sales analysis should form part of a broader sales information system, but many firms are unsophisticated in this respect and hold inadequate information (Kotler, 2009). Information is vital because understanding consumers at sector level aids business strategy. Indeed, within the machinery sector, client naivety, accessibility to sales data and even political climate, all influence purchasers' habits (Holt and Edwards, 2012). These benefits help explain why many studies have targeted the subject in myriad market sectors and yet, this is not the case for the construction machinery sector. Given this, the present study's aim is: to increase understanding of the UK off-highway construction machinery market and its consumers through analysis of new-sales data. Associated objectives are to consider the market and consumption through these findings and identify key areas for future research, especially, regarding development of complex sales forecasting models.

\section{Method}

Data representing total sales (of the ten machinery items in Table 1) were sourced through the authors' network of machinery professionals and in particular, from a consultancy specialising in capital industries (Sharp, 2011). Initial graphical analysis of total sales was used to identify peaks, trend and effects of the economic climate. Use of graphical methods in this way is a recognised approach to understanding data, that can be further studied using more formal methods if desired (Gnanadesikan, 1983). Descriptive analysis of all machinery types confirmed salient statistical features, in particular, 'higher' and 'lower' volume sales that were used to delineate data sub-sets in subsequent analyses.

The Pearson Product Moment correlation coefficient (r) (Colman and Pulford, 2006: p30) was used to highlight exploratory associations between data relating to machinery type sales and annual sales portfolios. Prior to this, sales data were tested for normality (a prerequisite to the Pearson test) and 
were found appropriately 'normal', except for CTL which were positively skewed (hence, CTL statistics are viewed with caution). Autocorrelation functions $\left(r_{k}\right)$ were also derived to observe selfcorrelations of some of the sales data time series $(Y t)$ using various lags $\left(r_{k}=r_{Y t, Y t-k}\right)$. As a basis for interpretation of statistical association, Salkind's (2010) guidance was used such that: $r \geq 0.41 \leq 0.6=$ 'moderate' relationship; $r \geq 0.61 \leq 0.84=$ 'strong' relationship; and $r \geq 0.85=$ 'very strong'. Significance of $r$ is interpreted conventionally as $p<0.05=$ 'statistically significant', and $p<0.01=$ 'highly significant'.

From the Pearson correlation analysis, a portfolio 'change-point' was identified (see later), which provided opportunity for subsequent pre- and post-change-point analyses. Finally, correlation analysis of annual sales volumes to values of construction output were undertaken; from which several associations were shown. Three particular machine type (MEXC, CEXC and WHL) models were developed and tested. Although based on numbers, analyses as presented here are generally termed descriptive, because they use sales to 'describe' market characteristics (Malhotra and Birks, 2006).

\section{Analysis and Results}

\section{Total sales for the period}

Figure 2 is a plot of total sales for all ten machinery items combined for the period 1990-2010 inclusive. Because annual sales movement is transitional, a smoothed curve is used to display the annual data points as a continuous trend (ditto similar Figures). Total sales in 1990 were 13,257 units which was $26 \%$ down on the previous year. The following two years' sales also declined markedly (35\% and $1 \%$ respectively) before recovering in 1994 to 18,392 units then tailing off slightly until 1998. This demonstrates negative impact upon machinery sales of the early 1990 s UK recession, at the onset of which, UK gross domestic product (GDP) contracted over five consecutive quarters (BBC, 2011). Similar effect on sales is even more visible commencing just prior the 2008 recession (ibid.). Here, sales fell steeply from a peak of 36,305 units in 2007 ; to 26,956 units in 2008 ; and 15,500 units in 2009. Sales began to recover in 2010 . 
The autocorrelation function for this time series showed a very strong relationship $\left(r_{l}=0.79, p<0.01\right)$ between adjacent years' sales; a moderate relationship $\left(r_{2}=0.50, p<0.01\right)$ given a 2 year lag and less than moderate association $\left(r_{k}<0.33\right)$ with a lag of three years or more. Notwithstanding fluctuations in demand over the period, the polynomial trend (dotted line on the Figure) with a good $\mathrm{R}^{2}$ of 0.9 confirms sales have increased and suggests growth post-2012 [reliable 2011 data were unavailable at time of writing].

[Figure 2]

\section{Descriptive analysis of machinery type sales}

Table 2 presents descriptive statistics for all data series viz: minimum (units sold in any one year); maximum (ditto); skewness; autocorrelation function $\left(r_{I}\right)$; mean (annual for the period); standard deviation; and rank (based on mean). The bestselling items in any year (all achieved in 2007) were MEXC (13,150 units), TELH (8,540 units) and CEXC (8,350 units). These achieved the same rankings in respect of mean sales, at 6,062, 4,699 and 3,633 units respectively. Lowest sales were attributed to CTL but this item did not enter the market until 2004 (10 units) and subsequently only averaged 31 units p.a. 2004-09 inclusive (accounts for CTL data skewness mentioned earlier). For the purpose of subsequent analyses, two classes of 'higher' and 'lower' volume sales were defined: higher volume represented $>2,900$ units p.a. average (MEXC, TELH, CEXC, BHOE) and lower volume represented $<1,000$ units (all remaining machinery types). The single lag autocorrelation function $(\mathrm{ACF})^{[2]}$ confirms that time series data for MEXC and CTL exhibit a 'very strong' trend $\left(r_{1} \geq 0.85, p<\right.$ 0.05); CEXC, BHOE, WEXC and TELH exhibit a 'strong' trend $\left(r_{l}>0.61 \leq 0.84, p<0.05\right)$; and ADT, RDT, WHL and SSL data were more random.

[Table 2] 


\section{Correlation analysis of sales by machinery type}

Table 3 is a correlation matrix for annual sales per machinery types; the three very strong, highly significant levels of association are highlighted in bold. These coefficients are all positive, indicating that high numbers of sales in one product relate to high numbers in its associated product(s). This analysis identifies: sales of mini-excavators show highly significant, very strong association with sales of crawler excavators $(r(10)=0.95, p \leq 0.01)$; and sales of telehandlers show highly significant very strong association with sales of crawler excavators $(r(10)=0.89, p \leq 0.01)$ and, mini-excavators $(r(10)$ $=0.90, p \leq 0.01)$

[Table 3]

\section{Analysis of annual sales portfolio}

A similar analysis was performed on the annual UK portfolio of sales and the resulting correlation matrix is shown in Table 4. This identified that for years 1990 to 1997 inclusive, there was significant association between each of these years' portfolio of sales and their subsequent, (approximately) four years (also borne out by the autocorrelation statistic at $r_{4} \leq 0.20, p<0.01$ ). That is, the proportions of machinery types sold in each of the years 1990-97 remained similar for (approximately) four years afterwards, but following 1997 this annual portfolio changed such that the proportions sold in 1998 remained significantly similar up until 2010. Therefore, 1997 was designated a 'change point' - the juncture when annual sales represented by numbers of each machinery type, settled into proportions that have since remained similar.

[Table 4]

More detailed graphical analysis of sales pre- and post-change point was undertaken to compare the four higher volume types during each of these periods. Figure 3 shows that pre-change point the market was led by telescopic handlers and mini-excavators. Post-change point, sales of mini- 
excavators and crawler excavators increased, while telehandlers slowed markedly and backhoe loaders even more so. Backhoe loaders are the only item whose sales trend declined over the entire period of study as confirmed by the polynomial trend line $\left(\mathrm{R}^{2}=0.83\right)$.

\section{[Figure 3]}

\section{Comparison of machinery sales to value of construction outputs}

Given that a primary market for off-highway machinery is the construction sector, total annual sales were compared to UK construction output data (current prices, £M), for the period 1997—2010 inclusive (Construction Statistics Annual, 2011). Correlation analysis was used as a basis for exploring potential sales forecasting models; tentatively within the present study and as a possible fertile avenue for future research. Three construction data sets were used: (i) value of housing completions (public and private combined); (ii) value of all new work; and (iii) value of repair and maintenance. These data represent building, civil engineering and specialised activities' output (ONS, 2011) and therefore, embrace all types of construction machinery consumer: from those using mini-excavators on minor works, to main contractors using the largest types of earthmoving and demolition machinery.

The analysis identified strong (significant) association between all machinery sales and repair and maintenance $(r(4)=0.60, p \leq 0.05)$; and strong (highly significant) association with all new work $(r(4)$ $=0.74, p \leq 0.01$ ). The strongest (highly significant) association existed with value of new housing $(r(4)=0.84, p \leq 0.01)$ - shown graphically in Figure 4 where new housing (lowermost line) is compared with all machinery sales (solid line). This relationship is more apparent if the maximum value of housing is brought to the same numerical peak as maximum sales (2007) by applying the multiplicand $(36,305$ all machinery $\div 24,919$ all housing $=) 1.456$ to housing data (uppermost dashed line in the Figure).

\section{[Figure 4]}




\section{Comparison of machinery sales to values of construction outputs}

Association was further investigated by performing correlation analysis among the ten machinery types 1997-2010. Table 5 shows correlation coefficients with those 'very strong' $(>0.85)$ highlighted in bold. Two machine types correlated with new housing data: crawler excavators $(r=0.9)$; and miniexcavators $(r=0.85)$. Wheeled loaders meanwhile, correlated with all new work $(r=0.86)$. New housing and all new work output data peaked in 2007, as did these three types of machine sales. So using a method similar to that described earlier to synchronise respective peaks, the following multipliers were derived: $(24,919$ new housing $\div 8,350$ CEXC $)=2.9 ;(24,919$ new housing $\div 13,150$ $\mathrm{MEXC})=1.9 ;(81,391$ all new work $\div 1,320 \mathrm{WHL})=61.6$. By transposition, relationships between these construction value measures and machinery sales is formalised by:
$\mathrm{CEXC}^{-\mathrm{sales}_{i}}=\left(n h_{i} / 2.9\right)+/-e$
(eq. 1)
MEXC-sales $_{i}=\left(n h_{i} / 1.9\right)+/-e$
(eq. 2)
WHL-sales $_{i}=\left(a n w_{i} / 61.6\right)+/-e$
(eq. 3)

Where: CEXC-sales ${ }_{i}$, MEXC-sales $_{i}$ and WHL-sales ${ }_{i}$ are suggested crawler excavator, mini-excavator and wheeled loader annual sales for year $i$ respectively; $n h_{i}$ is housing value in year $i$; $a n w_{\mathrm{i}}$ is all new work value year $i$; and $e$ is error adjustment.

\section{[Table 5]}

Figure 5 contrasts these models with sales data of the three machinery types for the period 1990-2010 inclusive, along with 'predicted' sales until 2015. The uppermost solid line for example, models miniexcavator sales (eq. 2) and actual sales as shaded bars. Similarly, the lowermost dotted line models wheeled loader sales (eq. 3) and actual sales as light shaded bars. Regarding error, $e$ is such that the MEXC-sales model is pessimistic when overall sales trend is upward and optimistic when sales trend is downward; while CEXC-sales model is optimistic for the latter part of the period. Table 6 validates 
the models using ACF analysis, confirming very strong trend at one lag, strong trend at two lags and moderate trend at up to 5 lags; while $r_{k}$ is stronger among the models than actual sales data.

[Figure 5 and Table 6]

\section{Discussion}

Total sales trend for the period confirms a growing market, driven in part by industry's pursuit of increased productivity at minimal cost (that mechanisation can provide). At macro-level demand is also buoyed by population growth and its concomitant need for infrastructure; while demand portfolio is impacted by external factors such as legislation, that for example, has encouraged mechanised logistics handling. Resultantly for the case in point, increased telehandler (dedicated materials handling) and excavator (often used for object handling) sales, can be logically interpreted. Despite this growth, significant negative effects of macroeconomic downturn (1990 and 2008) on new machinery purchases are quite apparent. In a poor economic environment, investment in capital assets will typically decline, albeit demand for construction machinery is to some extent less affected due to the cushioning effect of large projects (Anon, 2008a). Based on 1990-2010 data, a polynomial trend predicts growth for combined sales of the machinery studied, at least for the short term. (Figure 2).

Analysis identified significant variation in sales volumes. The compact tracked loader sold only 11 units a year on average (wheeled loaders offer lower operating costs) while the increasingly popular mini-excavator sold an average 6,000 units. Four 'higher-volume' machine types (mini-excavator, telehandler, crawler excavator, backhoe loader) consistently outsold remaining types by an approximate factor of three. The mini-excavator and telehandler especially have become UK machinery items of choice; while the crawler excavator and backhoe loader have long been popular for construction, mainly because of their earthmoving and object handling versatility. 
Correlation analysis on machinery type sales data identified significant associations. First, as miniexcavator sales increase, so do crawler excavator sales. Second, when sales of telehandlers increase, so do those of crawler excavators and mini-excavators. Mini-excavators, crawler excavators and telehandlers are commonly found working alongside each other in construction and especially on housing projects; so greater demand for one type suggests greater demand for the other two. For manufacturers, these relationships might be worthy of further research, because if consumers tend to invest in these types simultaneously (high $p$ values would indicate this is not co-incidental), then maybe there is scope for production/ marketing/ sales strategies to exploit this?

Annual sales portfolio pre-change-point (Figure 3; <1997) may in part reflect entrance of relatively new machinery types into the market a few years earlier, most notably, the telehandler and the miniexcavator. Post change-point the mini-excavator outsold all other types and this popularity has been attributed to its small size, light weight, transportability, lower capital cost and versatility (Edwards and Holt, 2009b). Reduced backhoe loader sales in this latter period may be partly explained by increasing telehandler popularity - the backhoe loader is frequently used for materials handling (in addition to excavating) but tighter UK legislation regarding lifting operations has fuelled a shift to dedicated logistics machinery. Since 1998, sales of the mini-excavator, telehandler and crawler excavator relative to each other have remained comparable; and seem to account for the similarity in annual sales portfolio, witnessed since then.

Statistical association between total sales and the value of new housing can be elucidated by considering three of the higher volume machinery types. Telehandlers are popular in house building for materials loading (refer above); as are crawler excavators to dig foundations, install drainage and place heavy components; while mini-excavators are used for numerous tasks including minor drainage, landscaping and pavement construction. A buoyant housing market is associated with economic confidence and availability of finance - such characteristics equally pre-requisite to encouraging demand for construction machinery. Hence, not only does house building stimulate 
direct demand for machinery; both housing and machinery investment is desirous of positive economic conditions to underpin consumer confidence.

The highly significant $(p<0.01)$ associations between construction output measures and sales of machinery types can be interpreted as follows. Crawler excavators and mini-excavators correlate with new housing output ( $r=0.9$ and 0.85 respectively) which reflects that these types are used extensively in new housing as discussed above. Wheeled excavators are preferred (to their tracked counterparts) in repair and maintenance work $(r=0.92)$ mainly because in such work they are typically operating on existing pavements that would otherwise be damaged by tracked machines. Conversely, crawler excavators operate better than wheeled excavators on difficult ground which is why tracked variants are preferred for housing. Sales of the compact tracked loader correlated with repair and maintenance work $(r=0.89)$, but the skewed CTL data make inferences unreliable in this respect.

The three basic models of machinery type sales correlate well with their respective construction output measures ( $r>0.85, p<0.01$ in all cases). When tested on 1990-2010 housing data, the 'dip' in actual sales data (versus predicted) generally mirrors the recession of the early 1990s (cf. Figure 2), while disparity between actual and predicted for MEXC 1990-1993 also reflects the fact that this was a relatively new product at this time (i.e. not having established itself in the market). The models predict increasing sales until 2015, suggesting greatest demand will remain for the mini-excavator (Figure 5).

\section{Practical and geographical applications/limitations of the study}

The practical applications of this study principally relate to helping stakeholders (e.g. suppliers, OEMs, distributers, sales outlets) better understand the machinery market and its consumers, that their services and products supply. Especially, to: (i) inform marketing and planning strategy(ies) of businesses that seek to exploit trends for commercial purposes; (ii) describe the sector's clients (purchasing habits) and thereby aid availability of appropriate proportions of machines for sale and/or hire at a given time; and (iii) signpost future demand for development of operational plans that satisfy 
demand while avoiding 'costly' over-production. A secondary, application serves to engender wider academic debate on machinery sales and marketing, with a view to developing alternative (more accurate and comprehensive) forecasting models, in this underdeveloped realm of engineering and construction management research.

Practical limitations relate to the fact that this was primarily a study of the machinery market and its consumers, so development of forecasting models was a secondary objective. More comprehensive forecasting using: i) increased historical time series; and ii) broader macroeconomic data (e.g. breaking down construction demand into raw materials sales and possibly encompassing other industrial segments such as mining, road building etc.), could potentially offer greater practical impact. Additionally, the study's geographical focus, means that results may not be representative of other countries' machinery markets.

\section{Conclusions}

The primary contribution of this study is a deeper understanding of the UK new machinery market and the predilections of its consumers over the last two decades. In this respect, the main conclusions are as follows. Notwithstanding two UK recessionary periods (1990 and 2008), sales trend of new machinery is upward; although the latter recession has had a more adverse effect on sales than downturns of previous years. Uncertainty in world markets (and currencies) generally, suggests present sales may continue unpredictably and take longer to recover than previously. These unique conditions, might also affect the reliability of sales forecasting models.

Within the UK construction market, considerable variation in demand exists among machinery types but by far the most popular types are mini-excavator, telehandler, crawler excavator, and backhoe loader. Significant correlations between annual sales of some machinery types exist. In particular, sales of mini-excavators show highly significant, very strong positive association with sales of crawler 
excavators; while sales of telehandlers show highly significant very strong positive association, with those of crawler excavators, mini-excavators, and wheeled excavators.

A 'change-point' in annual sales portfolio is identified circa 1997. Prior to this date, annual portfolio changed about every four years but since 1998, proportions of machinery type sales have remained similar. The main changes in sales portfolio since 2007 have been a slowing of demand for telehandlers, a greater slowing of demand for backhoe loaders, and increased demand for miniexcavators. Total annual sales correlate with construction output statistics, in particular, the annual value (current prices, £M) of new housing. Three machinery types show very strong highly significant association with construction output: crawler excavators, mini-excavators and wheeled loaders.

These levels of association may be applied as 'rules of thumb' (in a UK context), for example, in helping predict machinery sales trend and are approximated viz: sales of crawler excavators in a given year, approximate to the total value of new housing completed for that year divided by 3 ; sales of mini-excavators in a given year, approximate to the total value of new housing completed for that year divided by 2 ; and sales of wheeled loaders in a given year, approximate to total value of all new construction work completed that year divided by 62 . These models predict an upward trend in sales until 2015, especially for mini- and crawler excavators.

\section{Notes}

[1] G8: government leaders from Canada, France, Germany, Italy, Japan, Russian Federation, United Kingdom and United States. BRIC: generally accepted acronym representing economies of Brazil, Russia, India and China.

[2] An alternative form of analysis could be mean absolute change - see Wallström and Segerstedt (2010). 


\section{References}

Anon (2008a). Plant Sales for 2009. Plant Managers Journal. Vol. 35, No. 12, p5. Surrey: Reed

Business Information Ltd.

Ashcroft, G. (2007). Backhoe Challenge. Plant Managers Journal. Vol. 34, No. 2, pp28-29. Surrey:

Reed Business Information Ltd.

BBC (2011). Economy Tracker. Accessed via: http://www.bbc.co.uk/news/10613201 (December, 2011).

Blythe, J. (2010). Marketing Planning: Strategy, Environment and Context. Harlow: Pearson Education UK.

Colman, A. and Pulford, B. (2008). A Crash Course in SPSS for Windows (3 ${ }^{\text {rd }}$ Edition). Oxford: Blackwell Publishing.

Construction Industry Forecasts (2012). Accessed via:

http://www.trada.co.uk/downloads/techinfo/Construction_Industry_Forecasts\%28Winter\%20201 1-12\%29.pdf (March, 2012).

Construction Statistics Annual (2011). Construction Statistics, No. 12, 2011 Edition. Accessed via: http://www.ons.gov.uk/ons/rel/construction/construction-statistics/no--12--2011edition/index.html (December 2011).

Cuganesan, S. (2008). Calculating Customer Intimacy: Accounting Numbers in a Sales and Marketing Department. Accounting, Auditing and Accountability Journal. Vol. 21, No. 1, pp78-103.

Bingley: Emerald.

Edwards, D. J. and Holt, G. D. (2009a). Construction Plant and Equipment Management Research: Thematic Review. The Journal of Engineering, Design, and Technology. Vol.7, No. 2, pp186206. Bingley: Emerald Group Publishing Ltd.

Edwards, D. J. and Holt, G. D. (2009b). New Stability Field Tests for Construction Excavators. Engineering, Construction and Architectural Management. Vol. 16, No. 4, pp. 337-352. Bingley: Emerald. 
Edwards D. J. and Holt, G. D. (2010a). Case Study Analysis of Construction Excavator H\&S Overturn Incidents. Engineering, Construction and Architectural Management. Vol. 17, No. 5, pp493-511. Bingley: Emerald Group Publishing Ltd.

EPA (2011). Clean Air Nonroad (sic) Diesel - Tier 4 Final Rule. Accessed via: http://www.epa.gov/nonroad-diesel/2004fr.htm (December 2011).

Gnanadesikan, R. (Ed.). (1983). Statistical Data Analysis. Proceedings of Symposia in Applied Mathematics, Vol 28. The American Mathematical Society.

Haycraft, W. R. (2011). History of Construction Equipment. Journal of Construction Engineering and Management. Vol. 137, No. 10, pp720-723. Virginia: The American Society of Civil Engineers. Hilletofth, P., Ericsson, D. and Christopher, M. (2009). Demand Chain Management: A Swedish Industrial Case Study. Industrial Management and Data Systems. Vol. 109, No. 9, pp1179-1196. Bingley: Emerald.

Holt, G. D. and Edwards, D. J. (2012). Innovation or Business Survival? A Preliminary, Qualitative, Study of Construction Plant Supply Chains. Construction Innovation: Information, Process, Management. Vol. 12, No 1. Bingley: Emerald Group Publishing Ltd.

Ivert, L. K. And Jonsson, P. (2010). The Potential Benefits of Advanced Planning and Scheduling Systems in Sales and Operations Planning. Industrial Management and Data Systems. Vol. 110, No. 5, pp659-681. Bingley: Emerald.

Kalchschmidt, M., Verganti, R. and Zotteri, G. (2006). Forecasting Demand from Heterogeneous Customers. International Journal of Operations and Production Management. Vol. 26, No. 6, pp619-638. Bingley: Emerald.

Kotler, P. (2009). Marketing Management: First European Edition. Harlow: Pearson Education UK. Lancaster, G. and Massingham, L. (2010). Essentials of Marketing Management. London: Taylor and Francis.

Malhotra, N. K., Birks, D. F. (2006). Marketing Research: An Applied Approach. Harlow: Pearson Education UK. 
Nakano, M. (2009). Collaborative Forecasting and Planning in Supply Chains. International Journal of Physical Distribution and Logistics Management. Vol. 39, No. 2, pp84-105. Bingley: Emerald. ONS (2011). UK Standard Industrial Classification 2007 (UK SIC 2007). Accessed via:

http://www.ons.gov.uk/ons/guide-method/classifications/current-standardclassifications/standard-industrial-classification/index.html (December, 2011).

Piercy, N. (1993). Sales Forecasting with Limited Resources: Part 1. International Journal of Retail and Distribution Management. Vol. 6, NO. 4, pp37-64. Bingley: Emerald.

Salkind, N. J. (2010). Statistics for People Who (Think They) Hate Statistics (2 ${ }^{\text {nd }}$ Edition). London: Sage.

Segerstedt, A. and Olofsson, T. (2010). Supply chains in the construction industry. Supply Chain Management: An International Journal. Vol. 15, No. 5, pp347-353. Bingley: Emerald Group Publishing Ltd.

Sharp, R. (2011). Data accrued through authors' personal correspondence with consultant owner of Sharp-Practice. See: http://sharppractice.eu/index.php (November, 2011).

Sleight, C. (2007). Industry Heavyweights. International Construction. Vol. 46, No. 3, pp15-18. Pennsylvania: KHL Group.

Smyth, H. (2000). Marketing and Selling Construction Services. Oxford: Blackwell Science Ltd.

Wallström, P. and Segerstedt, A. (2010). Evaluation of Forecasting Error Measurements and Techniques for Intermittent Demand. International Journal of Production Economics, Vol. 128, No. 2, pp625-636. Elsevier.

Wanke, P. F. and Zinn, W. (2004). Strategic Logistics Decision Making. International Journal of Physical Distribution and Logistics Management. Vol. 34. No. 6, pp466-478. Bingley: Emerald. 
Figure 1. Relationship of Supply Chain to Supply and Demand

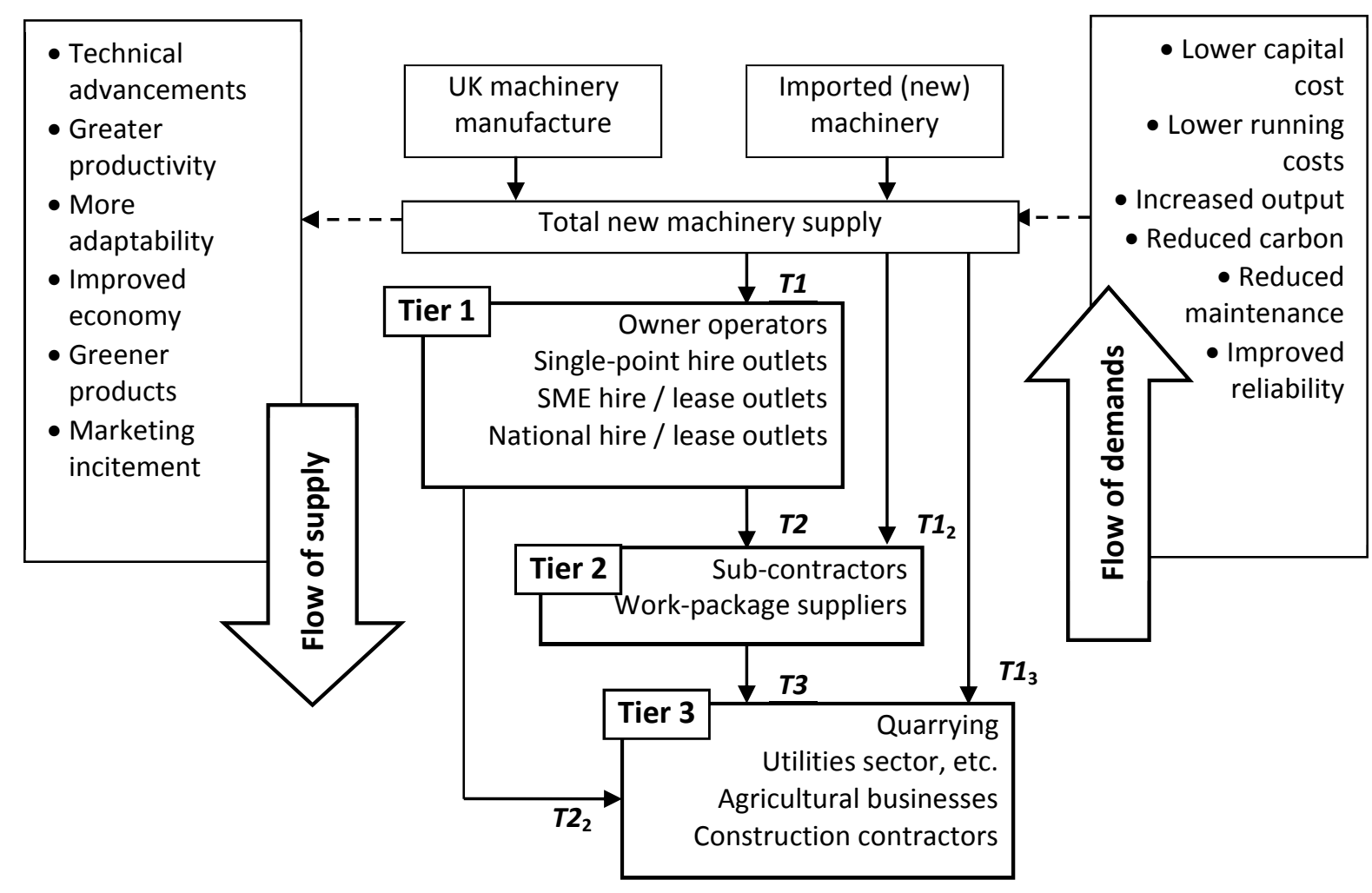

Source: Based on Segerstedt and Olofsson (2010); Holt and Edwards (2012) 
Figure 2. Total UK Off-highway Machinery Sales 1990-2010

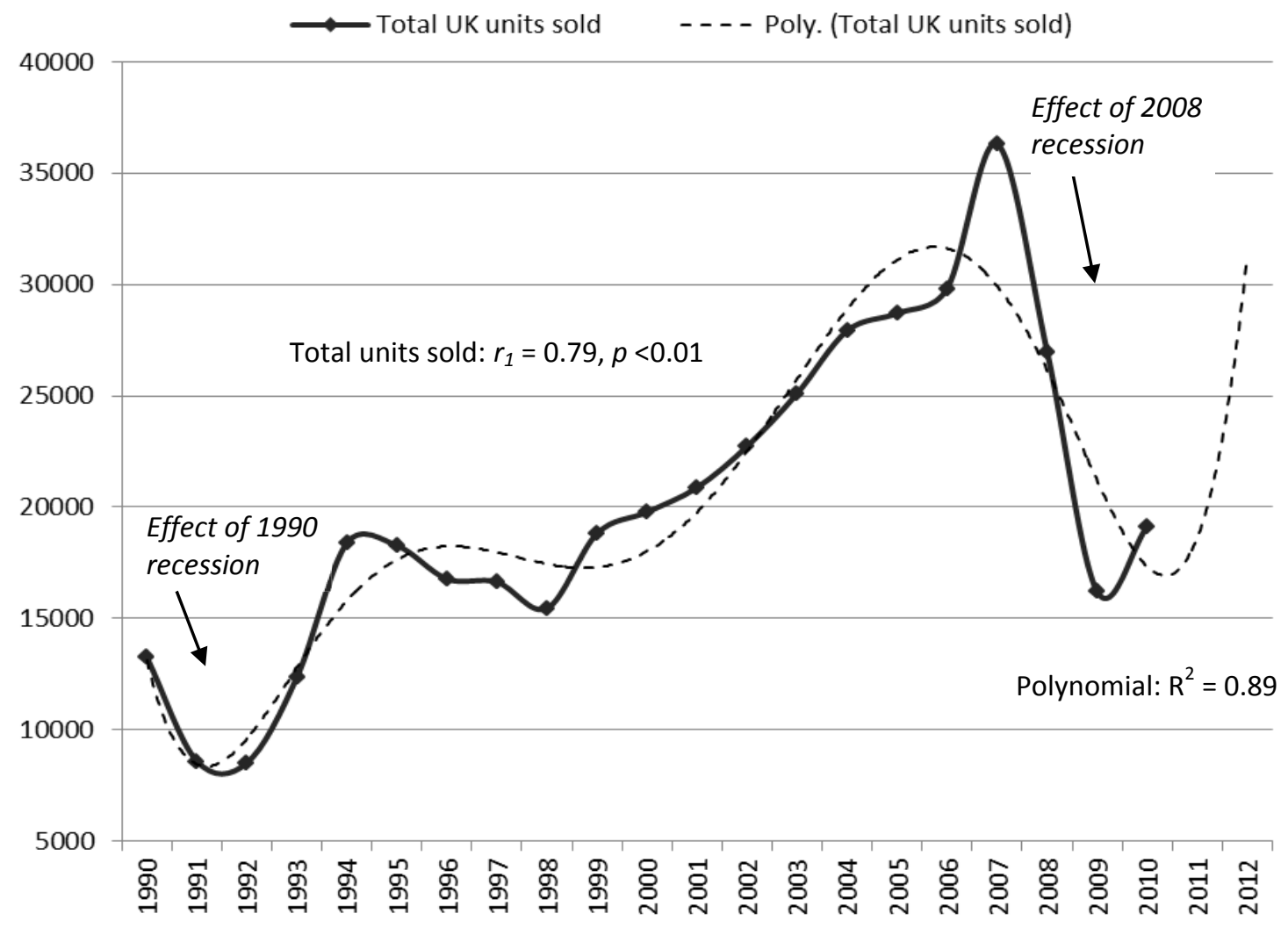

Source: Compiled from Sharp (2011) data

\section{Accepted Manuscript Not Copyedited}


Figure 3. Analysis of Higher Volume Products Pre- and Post-change Point

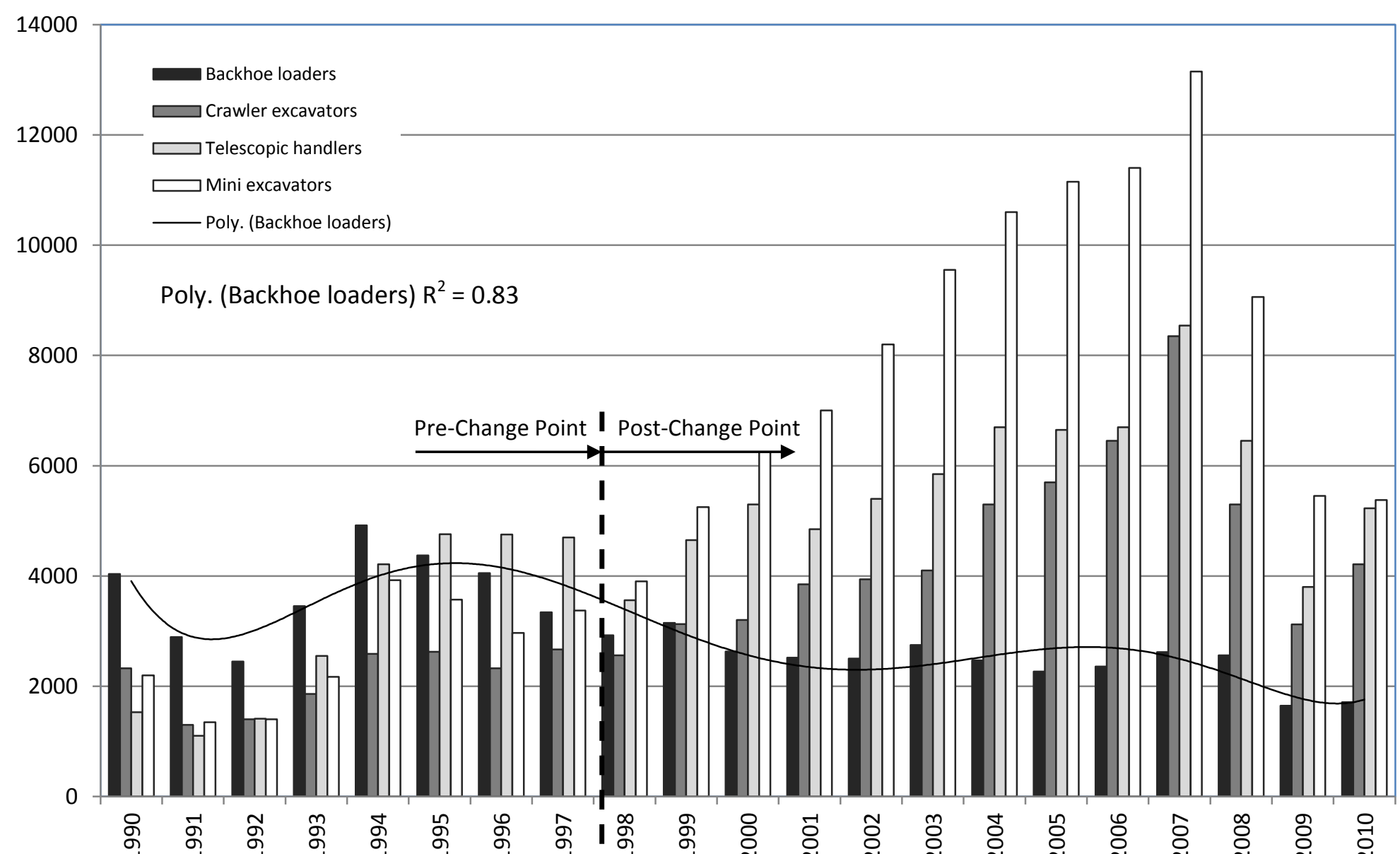


Figure 4. Graphical Comparison of all Types Machinery Sales and Housing Statistics

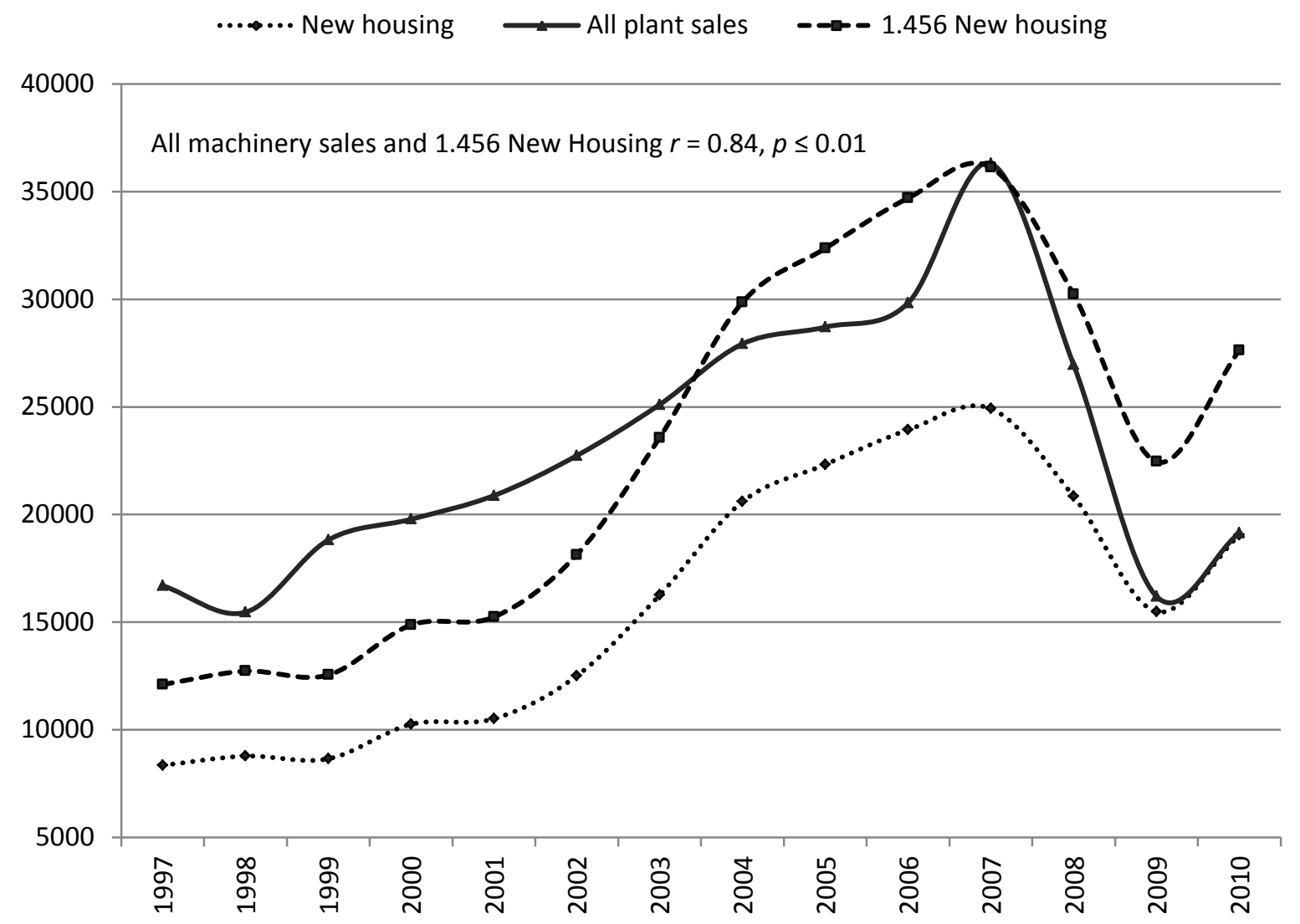

Source: Compiled from Sharp (2011) and Construction Statistics Annual (2011) data

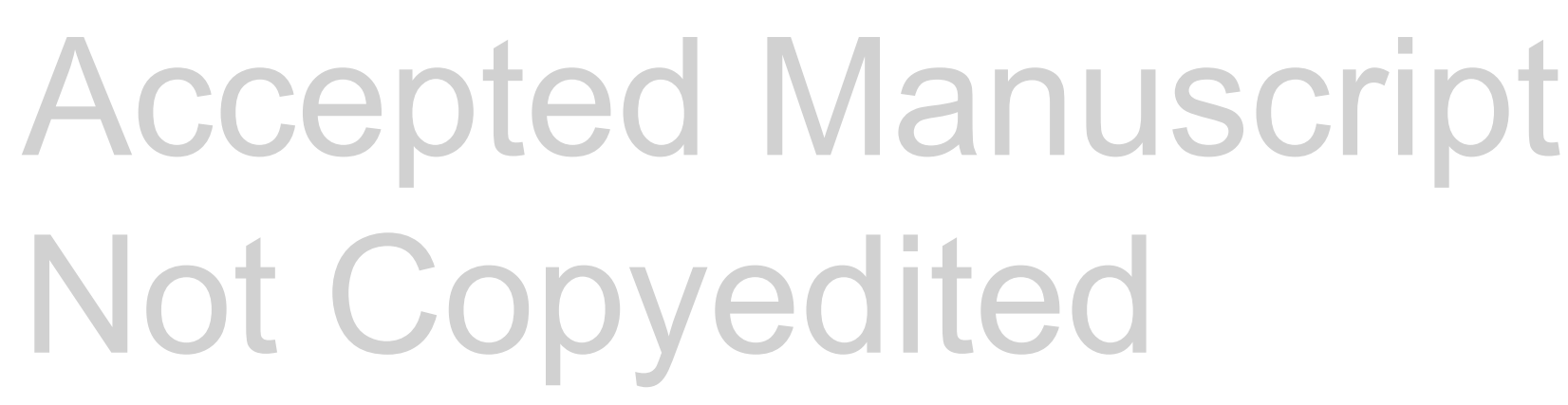


Figure 5. Models and Construction Data 1990-2010
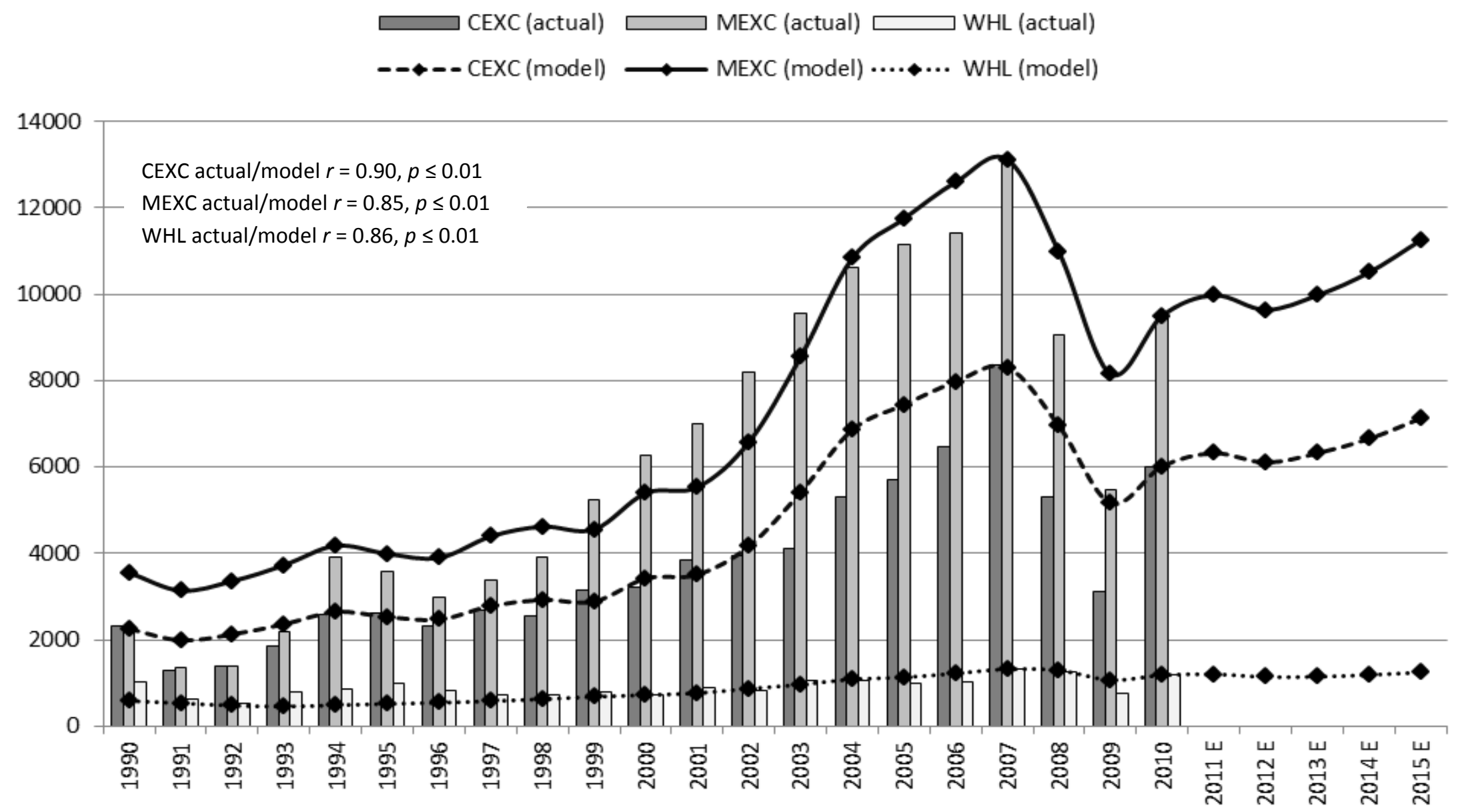

Source of housing/construction data (1990-2010): Construction Statistics Annual (2011)

Source of housing/construction data (2011-2015) Construction Industry Forecasts (2012) 
Table 1. Off-highway Machinery Types Studied, Acronyms and Brief Descriptions

\begin{tabular}{|c|c|c|}
\hline Machinery type & Acronym & Description and Typical Application \\
\hline Articulated Dump Truck & ADT & $\begin{array}{l}\text { Dump truck with articulated chassis, for transporting loose materials } \\
\text { and dumping them via hydraulically operated hopper }\end{array}$ \\
\hline Rigid Dump Truck & RDT & As per ADT but with rigid (non-articulated) chassis \\
\hline Crawler Excavator & $\mathrm{CEXC}$ & $\begin{array}{l}\text { ( } A k a \text { hydraulic excavator). For mass excavation and loading, can also } \\
\text { be fitted with specialist attachments for e.g. demolition }\end{array}$ \\
\hline Wheeled Backhoe & BHOE & $\begin{array}{l}\text { ( } A k a \text { backhoe loader). Multi-purpose machine with loading bucket at } \\
\text { front and excavating hoe at rear }\end{array}$ \\
\hline Mini-Excavator & MEXC & $\begin{array}{l}\text { (Aka compact excavator). General purpose tracked, small and } \\
\text { lightweight excavator usually fitted with dozing blade }\end{array}$ \\
\hline Wheeled Loader & WHL & $\begin{array}{l}\text { For loading loose or excavated material, often into another item of } \\
\text { machinery such as a dump truck }\end{array}$ \\
\hline Wheeled Excavator & WEXC & Similar to crawler excavator but lighter and with rubber tires \\
\hline Skid Steer Loader & SSL & $\begin{array}{l}\text { Small, manoeuvrable wheeled loader that locks a set of wheels to 'skid } \\
\text { steer' }\end{array}$ \\
\hline Compact Tracked Loader & CTL & Similar to wheeled loader but on tracks and typically less reach height \\
\hline Telehandler & TELH & All terrain telescopic forklift materials handler \\
\hline
\end{tabular}

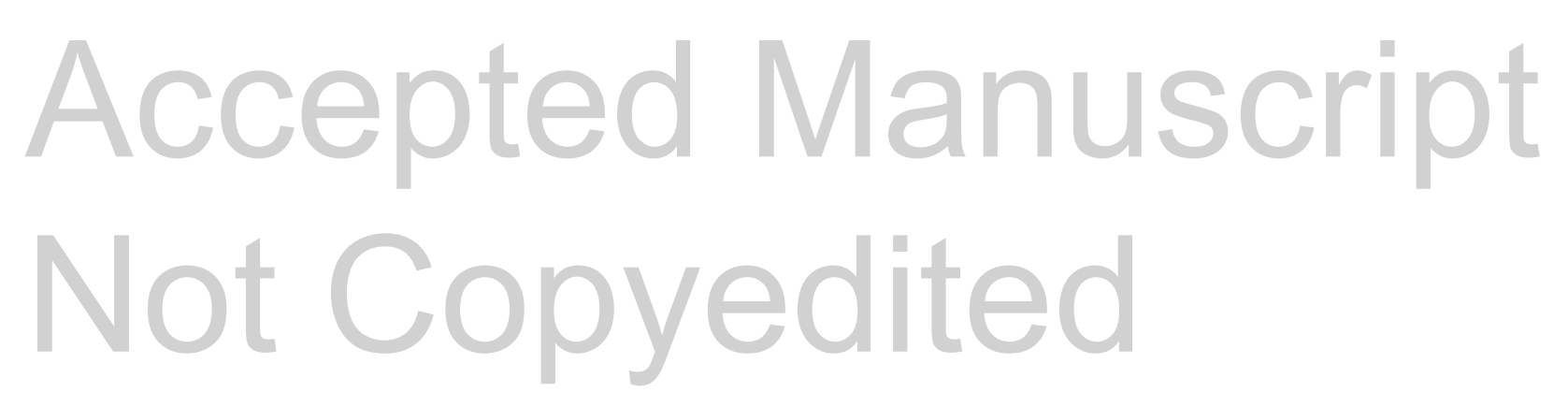


Table 2. Descriptive Statistics: Annual Units Sold (by type) 1990—2010

Machinery Type Min. Max. Skew $\operatorname{ACF}^{\mathrm{b}} \operatorname{Mean}^{\mathrm{c}, \mathrm{d}}$ S. Dev $^{\mathrm{d}}$ Rank $^{\mathrm{e}}$

\begin{tabular}{|c|c|c|c|c|c|c|}
\hline Articulated Dump Truck (ADT) & 215 & 765 & -0.51 & 0.38 & 501 & 148 \\
\hline Rigid Dump Truck (RDT) & 44 & 149 & 1.04 & $0.24 *$ & 76 & 26 \\
\hline Crawler Excavator (CEXC) ${ }^{\mathrm{a}}$ & 1,300 & 8,350 & 1.06 & 0.79 & 3,633 & 1,769 \\
\hline Wheeled Backhoe (BHOE) $^{\mathrm{a}}$ & 1,650 & 4,920 & 0.82 & 0.64 & 2,934 & 838 \\
\hline Mini-Excavator (MEXC) ${ }^{\mathrm{a}}$ & 1,350 & 13,150 & 0.47 & 0.88 & 6,062 & 3,602 \\
\hline Wheeled Loader (WHL) & 535 & 1,320 & 0.40 & 0.44 & 893 & 200 \\
\hline Wheeled Excavator (WEXC) & 145 & 675 & 0.31 & 0.79 & 370 & 135 \\
\hline Skid Steer Loader (SSL) & 650 & 1,229 & 1.13 & $0.21 *$ & 847 & 125 \\
\hline Compact Tracked Loader (CTL) & 0 & 48 & 1.23 & 0.85 & 11 & 17 \\
\hline Telehandler (TELH)* & 1,100 & 8,540 & -0.30 & 0.75 & 4,699 & 1,909 \\
\hline
\end{tabular}

a'Items designated 'higher-volume' for this study

${ }^{b}$ Autocorrelation function one lag, asterisk denotes $p>0.05$

${ }^{c}$ Per annum for the period

${ }^{d}$ Decimal places ignored

${ }^{e}$ Based on largest mean sales 
Table 3. Correlation Matrix for Machinery Sales 1990-2010 by Types

\begin{tabular}{|c|c|c|c|c|c|c|c|c|c|c|}
\hline ADT & 1 & & & & & & & & & \\
\hline RDT & 0.35 & 1 & & & & & & & & \\
\hline CEXC & $0.57 * *$ & -0.19 & 1 & & & & & & & \\
\hline BHOE & 0.33 & $0.67 * *$ & -0.43 & 1 & & & & & & \\
\hline MEXC & $0.55^{* *}$ & -0.29 & $0.95 * *$ & -0.47 & 1 & & & & & \\
\hline WHL & $0.57 * *$ & 0.18 & $0.79 * *$ & -0.9 & $0.70^{* *}$ & 1 & & & & \\
\hline WEXC & 0.4 & -0.16 & $0.80 * *$ & -0.43 & $0.78 * *$ & $0.79 * *$ & 1 & & & \\
\hline SSL & 0.26 & $0.61 * *$ & -0.28 & $0.63 * *$ & -0.36 & -0.02 & -0.46 & 1 & & \\
\hline CTL & 0.04 & -0.23 & $0.66^{* *}$ & -0.57 & $0.53 *$ & $0.62 * *$ & $0.80 * *$ & -0.49 & 1 & \\
\hline \multirow[t]{2}{*}{ TELH } & $0.63 * *$ & -0.21 & $0.89 * *$ & -0.28 & $0.90 * *$ & $0.71 * *$ & $0.80 * *$ & -0.32 & $0.50 *$ & 1 \\
\hline & ADT & RDT & CEXC & BHOE & MEXC & WHL & WEXC & SSL & CTL & TELH \\
\hline
\end{tabular}

$* * p \leq 0.01$

$* P \leq 0.05$

\section{Accepted Manuscript Not Copyedited}


Table 4. Correlation Matrix for Annual Portfolio of New UK Machinery Sales 1990-2010

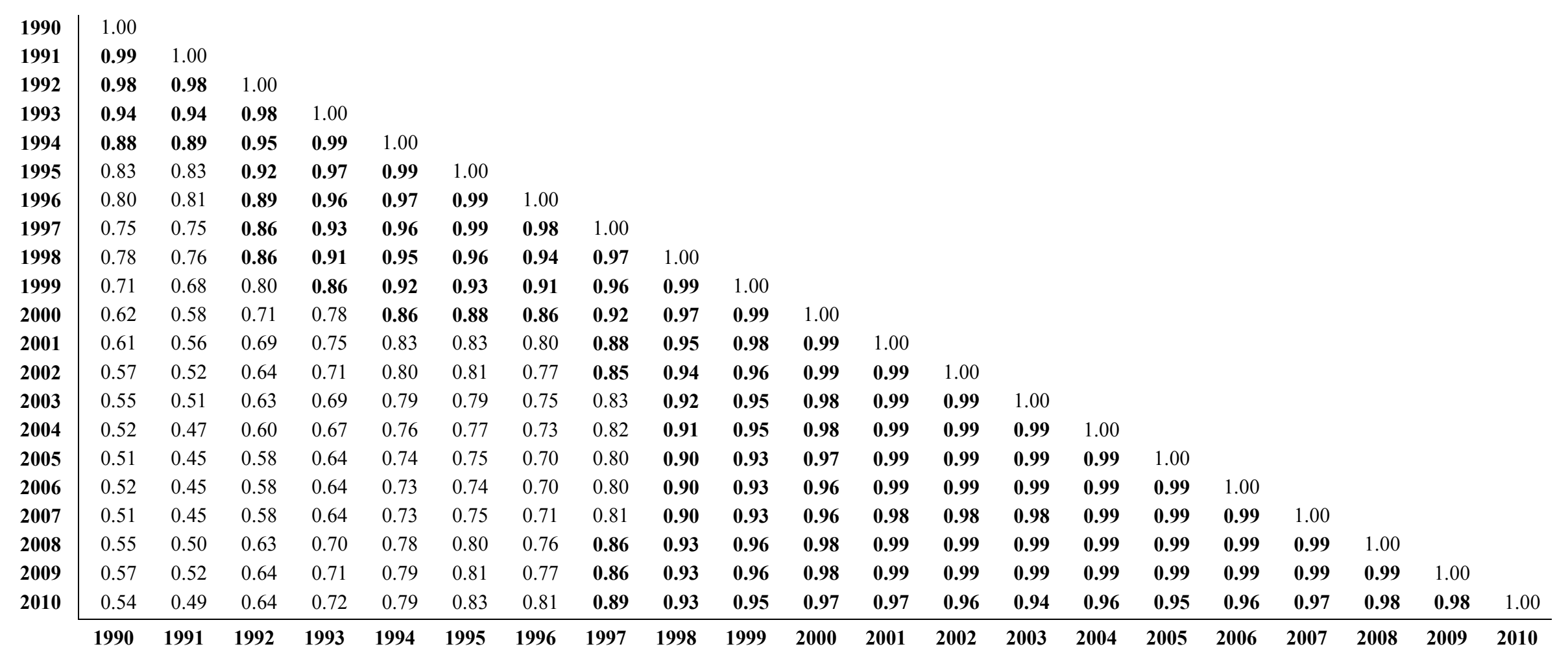

Highlighted bold: 'very strong' association; $p \leq 0.01$

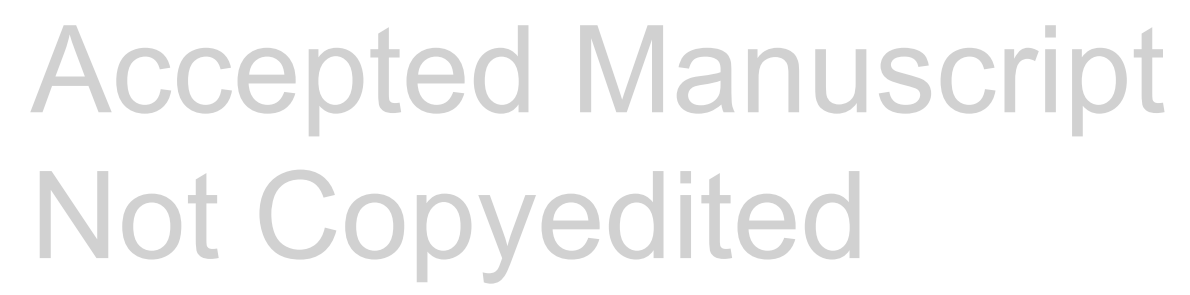


Table 5. Correlation Matrix for Construction Outputs and Machinery Types

\begin{tabular}{l|lll} 
New-housing & 1.00 & & \\
All_new & $0.96^{* *}$ & 1.00 & \\
All_rep_main & $0.89^{* *}$ & $0.97^{* *}$ & 1.00 \\
ADT & 0.33 & 0.21 & 0.07 \\
RDT & -0.08 & -0.17 & -0.19 \\
CEXC & $\mathbf{0 . 9 0}^{* *}$ & $0.82^{* *}$ & $0.69^{* *}$ \\
BHOE & -0.50 & $-0.62^{*}$ & $-0.70^{* *}$ \\
MEXC & $\mathbf{0 . 8 5}^{* *}$ & $0.75^{* *}$ & $0.63^{*}$ \\
WHL & $0.85^{* *}$ & $\mathbf{0 . 8 6} * *$ & $0.78^{* *}$ \\
WEXC & $0.83^{* *}$ & $0.90^{* *}$ & $\mathbf{0 . 9 2 * *}$ \\
SSL & $-0.54^{*}$ & $-0.59^{*}$ & $-0.67 * *$ \\
CTL & $0.74^{* *}$ & $0.86^{* *}$ & $\mathbf{0 . 8 9 * *}$ \\
TELH & $0.82^{* *}$ & $0.72^{* *}$ & $0.58^{* *}$ \\
\cline { 2 - 4 } & New- & All & All rep \\
& housing & new & main
\end{tabular}

$* * p \leq 0.01$

$* P \leq 0.05$

\section{Accepted Manuscript Not Copyedited}


Table 6. ACF Validation of the Models

\begin{tabular}{|c|c|c|c|c|c|c|}
\hline \multirow[b]{2}{*}{ Lag } & \multicolumn{2}{|c|}{ CEXC } & \multicolumn{2}{|c|}{ MEXC } & \multicolumn{2}{|c|}{ WHL } \\
\hline & $\begin{array}{c}\text { Model } \\
\text { sales }\end{array}$ & $\begin{array}{c}\text { Actual } \\
\text { sales }\end{array}$ & $\begin{array}{c}\text { Model } \\
\text { Sales }\end{array}$ & $\begin{array}{c}\text { Actual } \\
\text { sales }\end{array}$ & $\begin{array}{c}\text { Model } \\
\text { sales }\end{array}$ & $\begin{array}{c}\text { Actual } \\
\text { sales }\end{array}$ \\
\hline$r_{1}$ & 0.90 & 0.79 & 0.90 & 0.88 & 0.91 & 0.44 \\
\hline$r_{2}$ & 0.76 & 0.55 & 0.76 & 0.68 & 0.81 & $0.20 *$ \\
\hline$r_{3}$ & 0.58 & 0.42 & 0.58 & 0.50 & 0.65 & $0.19^{*}$ \\
\hline$r_{4}$ & 0.38 & 0.25 & 0.38 & 0.34 & 0.47 & $0.15^{*}$ \\
\hline$r_{5}$ & 0.20 & 0.15 & 0.20 & 0.20 & 0.29 & $0.08^{*}$ \\
\hline
\end{tabular}

$* p>0.05$ 